\title{
EDUCAÇĀo SANITÁRIA EM AMBULATÓRIO DE PEDIATRIA. O TRABALHO DE UMA ENFERMEIRA VOLUNTÁRIA
}

\author{
Maria do Carmo Marcondes Pincherle*
}

PINCHERLE, M. do C.M. Educaçāo sanitária em ambulatório de Pediatria. O trabalho de uma enfermeira voluntária. Rev. Esc. Enf. USP, São Paulo, 14 (3): 271-273, 1980.

A autora relata sua experiencia como enfermeira voluntária num ambulatório de Pediatria pertencente a uma entidade assistencial privada sem fins lucrativos.

A Assistência Social Santo Antonio (ASSA) é uma obra particular fundada em 1950, sem fins lucrativos. A enfermagem é dirigida por Irmãs da Ordem de São Camilo e tem como supervisora uma enfermeira sanitarista que dá assistência técnica a todos os ambulatórios da região: Granja Viana, Caucaia do Alto, Vargem Grande, que estão ligados ao Centro de Saúde da Associação Hospital de Cotia.

A ASSA tem muitos outros setores de assistência social tais como: clube de mães, parque infantil, etc., mas este trabalho visa especialmente relatar a assistência dada à criança no ambulatório, que também assiste à mãe e o adulto.

O serviço conta com o trabalho de três pediatras. Dois deles trabalham duas manhãs por semana, dando assistência às crianças de zero a dois anos de idade. $O$ terceiro pediatra trabalha cinco tardes por semana num serviço aqui chamado de "pronto atendimento", que dá assistência a toda criança de qualquer idade que adoeça subitamente. São atendidas em média cento e sessenta crianças por mês.

O ambulatório para consulta das crianças de zero a dois anos de idade funciona às 2as. e 3as. feiras pela manhá.

A criança é registrada e a assistente social classifica a situação sócio-econômica da família. $\mathrm{O}$ ambulatório fornece leite e medicamentos às crianças das famílias mais carentes. Também a mãe sem recursos, que está amamentando, recebe suplemento de alimentação: "Plano de Gestal".

Toda a vacinação, Tríplice, Sabin, anti-variólica, anti-tetânica, anti-diftérica, BCG intra-dérmico, contra sarampo, é feita no ambulatório diariamente pela enfermagem.

$\mathrm{Na}$ pré-consulta são seguidos todos os procedimentos de enfermagem sistematizados: tomada de temperatura, tomada de estatura, verificação do peso, avaliação

Enfermeira voluntária. 
do estado de saúde e desenvolvimento da criança, separação das crianças em estado grave para fim de prioridade na consulta, encaminhamento à consulta.

O médico examina a criança, prescreve medicamentos, alimentação e vacinação, e orienta a mãe sobre o tratamento. Esta recebe do médico toda a orientação por escrito.

Após a consulta a mãe vai à pós-consulta com a auxiliar de enfermagem, que reforça a orientação sobre o tratamento, alimentação, higiene e vacinação, fala sobre a importância do retorno à consulta na data certa, para que o médico possa acompanhar bem o desenvolvimento da criança, marca no cartão a data de retorno ao ambulatório.

São feitos, também, pela enfermagem, curativos, injeções de urgência, inalações e coleta de sangue para exames laboratoriais.

O ambulatório conta com o serviço de uma enfermeira voluntária que dá plantão de quatro horas uma vez por semana. Por esta foi organizado um programa de educação sanitária para ser desenvolvido junto d̀s mães.

0 programa inclui os seguintes tópicos:

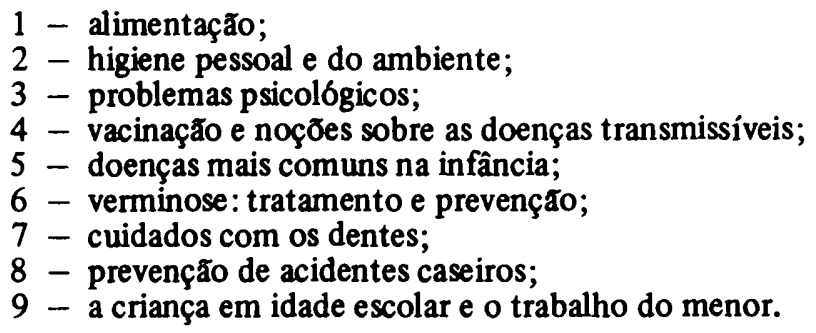

As palestras são feitas com o auxílio de cartazes bem simples, com muitas figuras e poucos dizeres, e os folhetos distribuídos pela Secretaria da Saúde. Nestas palestras usa-se vocabulário bem simples, ao nível de compreensáo das máes. Por exemplo não se fala em otite mas em ouvido inflamado e purgando; não se fala em coriza mas em nariz escorrendo, etc. São feitas perguntas às mães, pondo-as à vontade, para que participem da aula tomando esta mais viva e interessante.

Na primeira hora, quando as mães estão esperando a consulta, a enfermeira voluntária faz duas ou três palestras de duração de vinte a trinta minutos a grupos de cinco a seis mães cada um.

Na pós-consulta, quando a mãe é orientada pela enfermeira voluntária, toma-se nota numa ficha do nome da criança, seu problema atual de saúde e data de retorno à consulta, para que, na próxima vez, possa ser verificada a evolução da criança e possa ser cobrada da mãe a orientação recebida, caso ela não esteja seguindo corretamente as instruçðes. Anota-se também que palestra ela assistiu nesse dia. Por exemplo se a mãe assistiu a uma palestra sobre vacinaçæo e na próxima consulta a criança não estiver vacinada, ela será admoestada e a orientação será reforçada. É explicado sempre às mães que conhecimento gera responsabilidade. Se a mãe não souber da existência da vacina e a criança contrair a doença e vier a morrer, ela não é responsável; mas se ela for orientada e por displicência náo vacinar o filho, ela terá grande responsabilidade. 
As crianças que habitam os pequenos centros são muito mais saudáveis que aquelas das grandes cidades. Pelo ar sem poluição, ausência dos cortiços, as crianças são criadas com mais espaço, evitando, portanto, as contaminaçбes. Raramente uma criança aqui da região precisa de internação em hospital.

O principal problema destas crianças é a carência alimentar, principalmente a carência protéica, porque carne, leite e seus derivados săo os alimentos mais caros. $\mathrm{O}$ alto custo de vida é um problema político, que infelizmente não pode ser resolvido com aulas num ambulatório de pediatria. Essas crianças também comem muito pouca verdura devido ao péssimo hábito alimentar da famnlia brasileira, que se alimenta principalmente à base de hidrato de carbono.

Como muitas das famílias desta regiáo têm um pequeno quintal, incentivamos as mesmas a fazerem uma pequena horta e a criarem galinhas, para melhorar a alimentação das crianças.

Para grande consolo de quem trabalha educando o povo, não há uma mãe sequer que ache boa sua condição de analfabeta. Todas sem exceção querem que os filhos aprendam a ler e que tenham uma profissáo. Explicamos a elas que a base para isto é a higiene e a alimentação desde a primeira infância; que quem nã̃o for saudável e bem alimentado desde a primeira infância não se sairá na escola;e quem não estuda năo sai da condição de analfabeto dos pais.

Às mães que não trabalham fora de casa, procuramos incentivar para terem um trabalho. Exemplo: lavar roupa para ganhar, dar pensão, olhar uma criança da vizinha que trabalha fora, fazer costura ou tricô para vender, etc., sempre de acordo com o nível de capacidade e instrução das mães. A ASSA tem cursos de trabalhos manuais, costura, datilografia, etc. para as mães que estiverem interessadas.

A enfermeira voluntária e as auxiliares de enfermagem religiosas deste ambulatório há muitos anos dão orientação d̀ mães e pode-se constatar que já colheram bons resultados. A maioria das mães faz o pré-natal, a maioria das crianças está vacinada e a condição de saúde das crianças é razoável, dentro das precárias possibilidades econômicas e sociais das famílias.

Nas quatro horas semanais de trabalho da enfermeira voluntária, sáo feitas, em média, mensalmente, palestras a quarenta mães e orientadas individualmente oitenta mães. Este trabalho da enfermeira voluntária foi iniciado em abril de 1979.

Fica aqui uma sugestão para as enfermeiras afastadas da profissăo darem algumas horas semanais de seu tempo, para uma obra de caridade, como enfermeira voluntária.

PINCHERLE, M. do C.M. The work of a volunteer nurse. Rev. Esc. Enf. USP, São Paulo, 14 (3): 271-273, 1980.

The author describes her activities as volunteer in a pediatric health center belonging to a private non profit organization. 